\title{
Dressed, undressed, or both The case of Ewaw in Southeast Maluku
}

\author{
Aone van Engelenhoven
}

\begin{abstract}
This article discusses complexity and simplification in Ewaw (also known as Kei or Keiese), an Austronesian language in Southeast Maluku. Section 1 provides an introduction to the genetics, spelling, and phonology of this language, which is related to the Austronesian languages of Timor. There are two main dialects which subdivide into two variants each. Section 2 provides an overview of the productive inflection in Ewaw and its derivational morphology, of which only reduplication is still productive. It has two noun classes and four verb classes, seventeen derivational prefixes, and four derivational suffixes. Section 3 is a sketch of Ewaw syntax and deixis. It has twenty-four adverbial markers to encode direction and manner, which can all be analysed as serial verb constructions. Section 4 compares Ewaw grammar to languages in the region. Whereas Ewaw's petrified morphology is more complex than in any other language in the region, it now has the simplest morphology. Section 5 concludes that Ewaw's simplification without "shedding" its morphology is problematic.

\section{KEYWORDS}

Ewaw (Kei) language; Southeast Maluku; language simplification; comparative morphology.
\end{abstract}

\footnotetext{
Aone VAn Engelennoven took his PhD at Leiden University where he lectures Southeast Asian linguistics. His main research interests are the semiotics of oral traditions and the description of Indonesian and regional languages in insular Southeast Asia and the Malukan community in The Netherlands. His most recent publication is "Orality in Southeast Asia", in: Ganesh N. Devy and Geoffrey V. Davis (eds), Orality and language, pp. 9-33 (2020, New Delhi: Routledge India; Key Concepts in Indigenous Studies 4). Aone van Engelenhoven can be reached at: a.van.engelenhoven@hum.leidenuniv.nl.

(C) 2021 Faculty of Humanities, Universitas Indonesia

Aone VAn Engelenhoven | DOI: 10.17510/wacana.v22i2.1039.
} 


\section{InTROduction: ${ }^{1}$ Genetics, SPELLING, AND PHONOLOGY}

Ewaw is a Central Malayo-Polynesian language which is spoken as a first language in the Kei and Tayandu Archipelagoes, Southeast Maluku Regency, Maluku Province in the eastern part of the Republic of Indonesia. With its estimated number of 85,000 speakers according to the Ethnologue, it is one of the biggest languages in Maluku province (Paul Lewis, Gary F. Simons, and Charles D. Fennig 2015). Although this province is known for its linguistic diversity and severe language endangerment, Ewaw appears to be one of the most resilient languages in the region. Besides Ewaw, there are two other languages in the archipelago. At both ends of Yut Island, Bandanese, which was imported in the sixteenth century by fugitives from the Banda Islands in Central Maluku (James Collins and Timo Kaartinen 1998), is spoken. Directly to the west of the Tayandu Islands, Kur is spoken on the islands of Kur and Koimeer.

Although there is a large Ewaw-speaking diaspora throughout Indonesia, and even in the Netherlands, the Ewaw language is mainly spoken in the Kei and Tayandu Archipelagoes. It is also reported as a lingua franca on Kur and Koimeer and as a trade language used by non-Kei traders in the Aru Archipelago and northern Tanimbar.

Ewaw is generally sub-grouped with the languages of Tanimbar Island, although there has been a disagreement about the exact genetic divisions. Whereas Isidore Dyen's (1965) lexicostatistical calculations puts Fordata (North Tanimbar) and Ewaw into a single group in his Moluccan linkage, Mikhael Chlenov (1976), who used the same methodology, prefers to put Ewaw into a single group with Kur (to the northwest of the Kei Archipelago) within his South Moluccan sub-family. Collins (1982), basing himself on shared sound changes, concludes that Ewaw and three languages on Tanimbar, Fordata, Yamdena, and Selwasa, form one group. For the time being, he suggests that the southernmost language in the Tanimbar Archipelago, Selaru, might be not be included in this sub-group, because of its aberrant sound changes. The latter finding is confirmed by Roger F. Mills (1991), who removes Selaru from the Kei-Tanimbar Group and suggests it is more closely related to southwestern Malukan languages like Leti. ${ }^{2}$

\footnotetext{
1 The research underlying the present article was conducted within the framework of the Language Maintenance: An active approach project (Research No. A59803475) funded by the Australian Research Council (1998-2000). I would like to thank Mr Hans van Hernen (Malr@ foundation), Mr W. Rahayaan (Yar-Nain Association) for their support, Ms Fera UbroRahantoknam for being my language consultant, Mr Letsoin El Ew and Danny Hageman for our discussions on the topic. Special thanks to Jim Collins for his input. Of course, I am the only one to blame for any shortcomings. The references in square brackets relate to texts in H. Geurtjens (1924) which were analysed with Ms Fera Ubro-Rahantoknam.

2 A major reason to consider a closer like between Southwest Malukan languages and Selaru is the phenomenon of metathesis, for which the Southwest Malukan Leti language has become famous in the literature. According to Van Engelenhoven (2004), however, as a regional rather than a genetic feature, metathesis cannot be a decisive argument in sub-grouping.
} 
Since Collins (1982), it is generally agreed that the languages of Kei and Tanimbar have descended from Central Malayo-Polynesian through ProtoSoutheast Maluku (Collins 1982; Jock Hughes 1987; Mills 1991). One notable exception is Geoffrey Hull 1998, who considers the languages of the Kei and Tanimbar Archipelagoes and the languages of Southwest Maluku to be descendants of a single proto-language which is a sister language of ProtoTimor. $^{3}$

Hughes (1987) distinguishes two main Ewaw dialects, which will be referred to here as Islands Dialect and Mainland Dialect, respectively. ${ }^{4}$ The Islands Dialect is spoken on Roa Island and adjacent islands. This dialect enjoys the most prestige in the Kei Archipelago, because it is spoken in the Regency's capital Langgur, located on Roa Island, and because most previous research has focused on this dialect. Consequently, almost all published material on Ewaw mentioned by Ed Travis (1993) is in this dialect. In this article we consider the isolects mentioned in the Ethnologue (Tayandu, Ta'am, and Kai-Tanimbar) to be sub-dialects or local variants of the Islands Dialect. Although there is some lexical differentiation between these varieties, all share the notable sound change of $\#^{*} \mathrm{C}_{1} V \mathrm{C}_{2}>\# \mathrm{VC}{ }_{1} \mathrm{C}_{2}$ in pretonic position. Some examples are given in (1a).

(1a) Island Dialect

$\begin{array}{ll}\text { Roa Island } & \text { Kei-Tanimbar Island } \\ \text { Patbá.k } & \text { Patbá.k } \\ \text { rená- } \eta & \text { réna- } \eta \\ \text { nẹ rahán } & \text { nẹ ráhan } \\ \text { manút } & \text { mánut }\end{array}$

Mainland
North
tabáwk
Renó-n
nū rahán
hi:v

\section{GLOSS}

South

təbó.k 'tobacco' renó-n 'mother-1SG' nū rəhón 'my house' mənút, hi:v 'chicken'

The Mainland Dialect is spoken on Yut island. Although the Ethnologue refers to it as the Kei Besar dialect, one can actually distinguish between a Northern and a Southern variety which are phonologically different. The phonological make-up of the Northern variety is fairly conservative. The Southern variety, however, displays some exclusive mergers of vowels which might explain its

3 This language was labelled "Arafuric" in Hull (1998) and "Nautonic" in Geoffrey Hull and Sabil José Branco (2002/3). Van Engelenhoven (2009), however, indirectly questions the validity of this proto-language by grouping the Luangic-Kisaric languages in Southwestern Maluku together with Makuva and the Kairui-Waimaha-Midiki-Naueti dialect chain in Timor into a single East Group which descends from Proto-Timor. Hull's (1998) proposal rejects the Central Malayo-Polynesian hypothesis (Robert Blust 1993, see also Mark Donohue and Charles E. Grimes 2008) and the suggestion that the languages of the Kei and Tanimbar Archipelagoes are one genetic sub-group with the languages of the nearby Aru Archipelago as it was proposed by Collins (1982).

${ }^{4}$ In Ewaw the noun nuhu relates to both "land" and "island". The Indonesian Wikipedia mentions Nuhu Ten ((is)land big) 'Big Island' or 'Big Land' as an alternative name for Yut Island and Nuhu Yana-t ((is)land child-T) 'Small Island' or 'Small Land' as an alternative name for Roa Island. Geurtjens (1921a: 80) suggests in a footnote that Yut was supposedly a "motherland", a place of origin. These facts seem reminiscent of the reference to Timor Island as "Big Land" in the languages of Southwest Malukan islanders (for example, Leti: Ralïana) who also see Timor Island as the place from which their ancestors came. 
unintelligibility for Islands Dialect speakers, as reported by the Ethnologue.

The spelling used in this article was devised in Zwolle (The Netherlands) during a research period from 1998 to 2000 and intends to provide a unified orthography for all Ewaw dialects. In a previous stage of the language, the nuclei of final open post-tonic syllables of polysyllabic lexical morphemes were truncated. In the Islands Dialect, its main result was compensatory vowel lengthening in the remaining syllable. The Northern variant of the Mainland Dialect shows that, before this elision took place, final vowels were either metathesized before the preceding consonant or, alternatively, copied before the preceding consonant and then deleted.

\begin{tabular}{|c|c|c|}
\hline & $\begin{array}{l}{ }^{*} b a t \\
{ }^{*} m u\end{array}$ & $\begin{array}{l}>\quad \mathrm{I}: \mathrm{V} \\
>\mathrm{I}: \mathrm{r}\end{array}$ \\
\hline
\end{tabular}

As can be seen in $(1 b)$, only *i\# survived as a palatal glide in both variants of the Mainland Dialect, whereas *u\# only survived as a labial glide in the Northern variant. In the Southern variant it merged with the preceding vowel after metathesis. The conservative character of the Northern variant of the Mainland Dialect enables the researcher to extrapolate a process of synchronic metathesis. This is obscured by the vowel mergers in the Southern variant, whereas the vowels in the Islands Dialect were just truncated. (1c) shows that, in the phonological context, $\mathrm{V}[+$ high $] \mathrm{C}_{1} \#$, the high vowe ${ }^{5}$ metathesizes with $\mathrm{C}_{1}$ when a consonantal suffix is added: $\mathrm{C}_{1} \mathrm{~V}[+$ high $]-\mathrm{C}_{2}$.

\begin{tabular}{|c|c|c|c|c|c|c|c|c|}
\hline$(1 c)^{6}$ & GLOSS & Spelling & I & $\mathbf{N}$ & $\mathrm{S}$ & +C output & elling & GLC \\
\hline & & mail & [ma & [majl] & [msjl] & $\tau]$ & $m a$ & \\
\hline & $\begin{array}{l}\text { ‘skin' } \\
\text { 'sit' }\end{array}$ & $\begin{array}{l}\text { uil } \\
\text { douk }\end{array}$ & $\begin{array}{l}\text { [?u:1] } \\
\text { [do:k] }\end{array}$ & $\begin{array}{l}\text { [Pujl] } \\
\text { [dowk }\end{array}$ & $\begin{array}{l}\text { [?rjl] } \\
\text { [do.k] }\end{array}$ & $\begin{array}{l}\text { +n [Pulín] } \\
\text { +ng [fdokún }\end{array}$ & $\begin{array}{l}\text { ulin } \\
\text { (f)dokung }\end{array}$ & \\
\hline
\end{tabular}

Whereas the monosyllabic truncated lexical morphemes have a different phonological form in the respective dialects, the addition of a consonant suffix results in the same disyllabic form in the output. The consonant suffixes will be taken up in Section 2.

Both Ewaw dialects share the same inventory of fifteen consonants: $b$, $\mathrm{p}, \mathrm{w}, \mathrm{f}, \mathrm{m}, \mathrm{d}, \mathrm{t}, \mathrm{s}, \mathrm{n}, \mathrm{l}, \mathrm{r}, \mathrm{g}, \mathrm{k}, \mathrm{ng}$, h, and ' . ' Like most languages in the South Maluku - Timor region, Ewaw lacks a palatal set. It distinguishes a voiced and voiceless opposition in the labial, alveo-dental, and velar occlusive row, which Travis (1993: 674) acknowledges only for the alveo-dental row. For the labial row, he mentions only the voiced occlusive $[b]$, whereas for the velar

${ }^{5}$ In this perception, glides are allophones of high vowel phonemes.

${ }^{6} \mathrm{I}=$ Island Dialect, $\mathrm{N}=$ Northern variant of the Mainland Dialect, $\mathrm{S}=$ Southern variant of the Mainland Dialect, $+\mathrm{C}=$ consonant suffix.

$7<w>$ refers to either a voiced bilabial approximant [v] or a voiced labio-dental fricative [v] in initial and medial position, or to their idiolectic voiceless allophones in final position, $[\phi]$ or $[f]$, respectively. The apostrophe refers to a glottal stop [?]. The Northern variant of the Mainland Dialect has a uvular trill [R] where the other dialects have an alveolar trill $[\mathrm{r}]$ (see examples in (1a)). $<$ ng $>$ refers to a velar nasal [ $\eta]$. 
row he mentions only the voiceless occlusive [k]. Of the 2,064 words listed in Geurtjens' (1921b) dictionary, there are twelve words with [p] in initial position and only two with initial $[\mathrm{g}]$ which all derive from local Indonesian. The only consonant with allophonic variation is the voiced labial approximant which is realized in initial and medial position as a voiced bilabial approximant [v] or as a labio-dental fricative $[\mathrm{v}]$ and tends to be a voiceless bilabial or labio-dental fricative $[\phi]$ or $[\mathrm{f}]$ in final position in running speech.

There are both labial and palatal glides, whose occurrence, however, differs per dialect. The palatal off-glide in final position is audible in the Islands Dialect and the Northern variant of the Mainland Dialect. In the Southern variant of the Mainland Dialect it is audible only preceding codas and might variably have merged with the preceding vowel in final position in open syllables. In these positions, the palatal glide is written with $<i>$. In the initial position the Zwolle spelling follows the Indonesian orthography and uses $<y>$.

In the same way, the labial off-glide is written as $\langle\mathrm{u}\rangle$ in final position in open syllables and preceding codas. ${ }^{8}$ It has not been attested in an initial position. Also, the labial glide is clearly audible in the Islands Dialect and in the Northern variant of the Mainland Dialect, whereas in the latter dialect's Southern variant it might variably merge with the preceding vowel in final position in open syllables. (1b) above provides examples of glides before codas. Examples of glides in final position in open syllables are given in (2a), where the representation in the Zwolle spelling is printed in Italic.

yahau 'dog': I, N: [jaháw], S: [johó] or [johów]

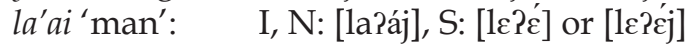

Both dialects have more or less the same vowel inventory: i, $u, e, \varepsilon, 0,0, a$. Exclusive to the Southern variant of the Mainland Dialect are the central and mid vowels [ə], [r], and[ø]. The Zwolle spelling refers to $[\varepsilon]$ and [o] with $<\mathrm{e}>$ and $\left\langle_{\mathrm{O}}\right\rangle$, respectively, and uses the digraphs $\left.<_{\mathrm{e} i}\right\rangle$ and $\left.<_{\mathrm{ou}}\right\rangle$ for $[\mathrm{e}]$ and $[\mathrm{o}]$, respectively. [ə], [ $\gamma]$, and $[\varnothing]$ are not indicated separately in the Zwolle spelling and use $\langle\mathrm{a}\rangle,\langle\mathrm{u}\rangle$, and $\langle\mathrm{o}>$ representing $/ \mathrm{a} /, / \mathrm{u} /$, and $/ \mathrm{o} /$, of which they are allophones. From a diachronic perspective, $[\mathrm{e}]$ and $[\varepsilon]$, and [o] and [o] seem to have been allophones of a single phoneme / $/$ and /o/ before the truncation of open final syllables mentioned above took place. If the final syllable contained a high vowel nucleus, the mid vowel in the preceding syllable was high-mid, whereas if the nucleus of the final syllable was a low vowel, the mid vowel in the preceding syllable was low-mid. This is still most clearly discernable in the Mainland Dialect in which the difference in height gave way to different phonemes in the morphemes in which the final syllable was truncated. In the Islands Dialect, on the other hand, it has become an allophonic variation. This is exemplified in (2b) by the lexical morphemes for 'black' and 'low tide' in the Islands and Mainland Dialects, respectively.

${ }^{8}$ For example, 'sit' in example (1c). 
(2b) met 'black': $\quad$ I, N, S: [me.t];

meit 'low tide': $\quad$ I: [me.t] $\sim$ [me.t], N: [me.t], S: [me.t] $\sim$ mejt].

The central high and mid vowels $[\gamma]$ and $[\varnothing]$ are exclusive to the Southern variant of the Mainland Dialect in which they are allophones of $/ \mathrm{u} /$ and /o/ when preceding /i/. Instead, the Northern variant displays the back allophones [u] and [o]. Whereas in both variants of the Mainland Dialect these allophones are followed by the palatal glide allophone [j] of /i/, the latter no longer exists in closed syllables in the Islands Dialect. This is exemplified in $(2 \mathrm{c})$.

$\begin{array}{ll}\text { wuil 'red': } & \text { I: [vu.1], N: [vujl], S: [vrjl]; } \\ \text { muir 'back': } & \text { I: [mu.r], N: [muje], S: [mrjr]; } \\ \text { boir 'steal': } & \text { I: [bo.r] [bo.r] [bu.r], N: [boje], S: [bøjr] } \\ \text { ohoi 'village': } & \text { I: [?ohój] [Pohoj], N: [?ohój], S: [?øhǿj]. }\end{array}$

Ewaw tends to have monosyllabic lexical morphemes. In most dialects the main stress falls on the final syllable. ${ }^{9}(2 \mathrm{~d})$ provides an example of a sentence in the Islands Dialect (I) and the Southern variant of the Mainland Dialect (MS) in the phonetic script and the Zwolle spelling (Z). The Ewaw examples in the remainder of the article will be written in the Zwolle spelling. ${ }^{10}$

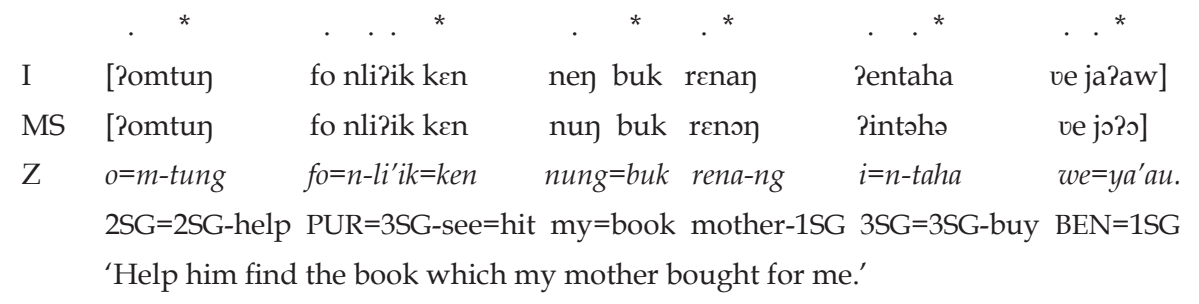

\section{Morphology: Productive inflection AND PETRIFIED Derivation}

Turning to singular and plural, in the first person plural, a distinction is made between what is generally called in Austronesian linguistics, 'inclusive' - including the Addressee in the narrated speech event - and 'exclusive' excluding the Addressee from the narrated speech event. The seven are listed in (3a) to which are added the correlating pronominal proclitics, prefixes, suffixes, and possessive proclitics. As becomes clear from (3a), Ewaw does not distinguish gender in its pronominal system.

\footnotetext{
${ }^{9}$ A notable exception appears to be the Kei-Tanimbar variant of the Islands Dialect in which stress falls on the penultimate syllable (see examples in (1a)). This might suggest that this isolect is instead a dialect of the closely related Fordata language in the Tanimbar Archipelago rather than of Ewaw proper. Ewaw appears to be the only iambic language in the regency.

${ }^{10}$ One exception must be noted. Whereas in the Zwolle spelling pronominal prefixes can occur separated from verbal stems by a space, here they are separated by a hyphen, whereas clitics will be marked by an equation symbol.
} 


$\begin{array}{llllll} & \begin{array}{l}\text { Personal } \\ \text { pronouns }\end{array} & \text { Proclitic } & \text { Prefix } & \text { Suffix }^{11} & \begin{array}{l}\text { Possessive } \\ \text { proclitic }\end{array} \\ \text { 1SG } & y a^{\prime} a u & y a \sim y o / u \sim y & (u)-, \varnothing- & -n g & n u n g \sim n e i n g^{12} \\ \text { 2SG } & o & o & m(u)- & -m & m u \\ \text { 3SG } & i & i & n(a)- & -n & n i \\ \text { 1PLINC } & i t & i & t(a)- & -d & \text { did } \sim \text { din } \\ \text { 1PLEX } & a m \sim a i m & a & m(a)- & -b & \text { mam } \\ \text { 2PL } & i m & i & m(i)- & -b & \text { bir } \\ \text { 3PL } & h i r & h i \sim i & r(a)- & -r & \text { rir }\end{array}$

Like its Southeast Malukan co-geners, Ewaw distinguishes alienable possession from inalienable possession, because of which it has two noun classes. Nouns referring to entities having inherent possessors, exemplified by 'hand' in (3b), are always marked by a pronominal suffix. Nouns which refer to entities which do not have an inherent possessor, exemplified by 'house' in $(3 b)$, can be marked by a possessive proclitic which agrees with the possessor in number and person.

$\begin{array}{ll} & \text { lima- 'hand'13 } \\ \text { my } & \text { lima-ng } \sim \text { limo-ng } \\ \text { your (SG) } & \text { lima-m } \sim \text { limo-m } \\ \text { his/her } & \text { lima-n } \\ \text { our (INC) } & \text { lima-d } \\ \text { our (EX) } & \text { lima- } b \\ \text { your (PL) } & \text { lima- } b \\ \text { their } & \text { lima-r }\end{array}$

rahan 'house'

nung $\sim$ neing $\sim$ ning rahan

mu rahan

ni rahan

did rahan

mam rahan

bir rahan

rir rahan

Whereas Geurtjens (1921a: 15) mentions fourteen nominal classifiers for Ewaw, Van Engelenhoven (2002) observes that only three of them - $u$ for boats, watu for globular objects and neutral ain - were still recognized by Ewaw consultants in Zwolle who had come from Indonesia fairly recently. The other Zwolle consultants, however, only used ain.

Except for the verb 'to drink', all Ewaw main verbs have an initial consonant. Very few verbs, exemplified in (3c) by 'to eat', have a pronominal prefix which consists of an initial consonant and a vowel (indicated in (3a) in between brackets). These prefixes usually occur before verbs with initial consonant clusters. One verb, 'to go', features labialization or palatalization of the initial consonant when prefixed with 1sG or 2sG and 2PL, respectively. ${ }^{14}$

\footnotetext{
${ }^{11}$ The Mainland Dialect changes a preceding /a/ for the [0] allophone of /o/ with the 1sG suffix, and for the [o] allophone with the 2sG suffix.

${ }^{12}$ In the Island Dialect often also written as ning (see Geurtjens 1921a).

${ }^{13}$ In the Mainland Dialect the first- and second-person singular suffixes change /a\#/ in the nominal stem to [0] and [o], respectively. The Mainland Dialect also features / $\mathrm{u} /$ in the 1sG possessive proclitic, whereas the Island Dialect has [e] or [1] which both are allophones of /e/. [1], however is often written as $<\mathrm{i}>$ in Indonesian, which explains why some Island Dialect consultants insisted on writing it with $<\mathrm{i}\rangle$ instead of $\langle\mathrm{e}\rangle$.

${ }^{14}$ The phenomenon is very common in the other languages of the Southeast Maluku Group,
} 
(3c)

\begin{tabular}{|c|c|c|c|c|c|c|}
\hline & -tetan 'cut' & -'out'do' & -fla 'run' & -'an 'eat' & -ein 'drink' & $-b a^{\prime} \mathrm{go}^{\prime}$ \\
\hline ISC & $y a=\varnothing-$ tetan & $y o=\varnothing-$-out $^{\prime}$ & $y a==^{\prime} u-f l a$ & $y u=\varnothing-^{\prime} a n$ & $y=\varnothing$-ein & $y a=\varnothing-b u a$ \\
\hline SG & $o=m$-tetan & $o=m-^{\prime}$ out & $o=m u-f l a$ & $o=m u-^{\prime} a n$ & $o=m$-ein & $o=m-b u a$ \\
\hline 3SG & $i=n$-tetan & $i=n$-'out $^{-}$ & $e=n a-f l a$ & $i=n a-{ }^{\prime} a n$ & $i=n$-ein & $i=n-b a, m-b a$ \\
\hline IPLINC & $i=t$-tetan & $i=t$-'out $^{\prime}$ & $i=t a=f l a$ & $i=t a-' a n$ & $i=t$-ein & $i=t-b a$ \\
\hline 1PLEX & $a=m-$ tetan & $a=m$-'out & $a=m a-f l a$ & $a=m a-^{-} a n$ & $a=m$-ein & $a=m-b a$ \\
\hline PPL & $i=m$-tetan & $i=m$-'out & $i=m i-f l a$ & $i=m i-{ }^{\prime} a n$ & $i=m$-ein & $i=m-b i a$ \\
\hline PL & $h i=r-\operatorname{tetan}$ & $h i=r$-out & $h i=r a-f l a$ & $h i=r a-^{\prime} a n$ & $h i=r-e i n$ & $h i=r-b a$ \\
\hline
\end{tabular}

As can be seen in the inflection of the verb 'to do' above, the /a/ in the proclitic of 1sG is exchanged to /o/ if the verb has an initial single consonant followed by /o/. In the case of 'drink', the vowel of the proclitic is deleted altogether, whereas in the case of 'to eat' it is exchanged for an $/ \mathrm{u} /$.

Dany Hageman (2004) describes seventeen prefixes and four suffixes which all reflect a system of derivational morphology which has become completely unproductive. Unlike Geurtjens (1921a) and Travis (1997), who consider them to be separate prefixes, he also acknowledges the infrequent sequences kafand kas- as combinations of $k a-$ (no. 14 in Table 1) with the reciprocal prefix $f$ - (no. 8 in Table 1) and the "temporary condition"15 prefix s- (no. 1 in Table 1), respectively. ${ }^{16}$ The square displays four verbal prefixes (no. 4-7) having an adjective or nominal counterpart (no. 14-17).

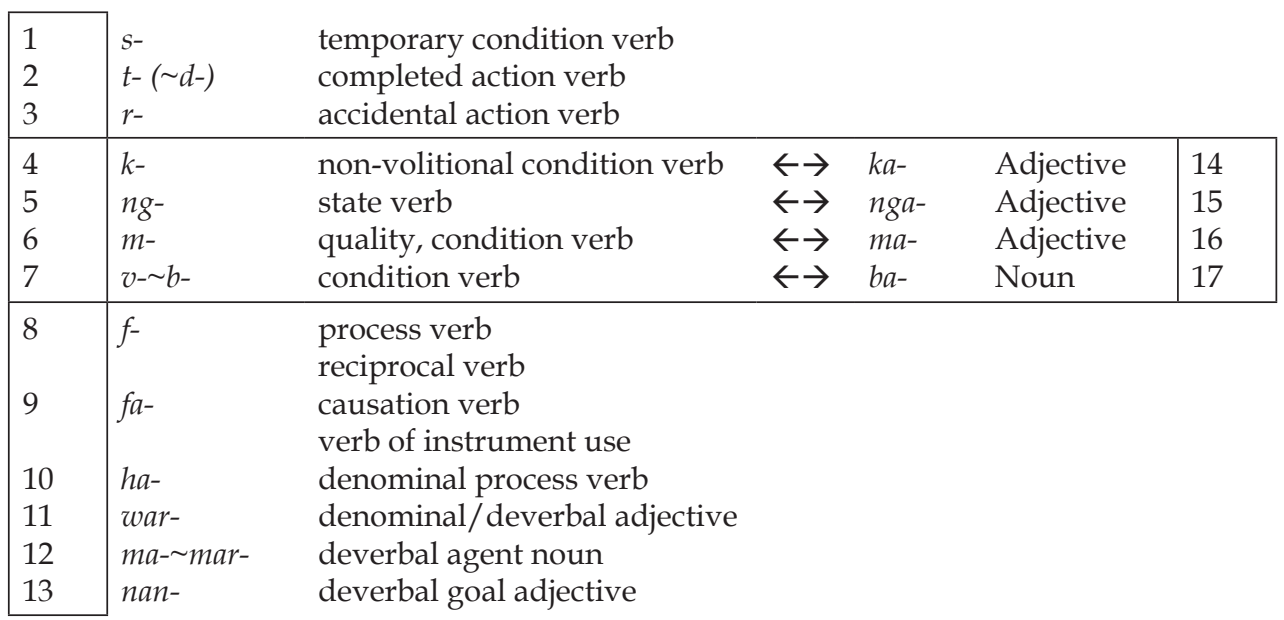

Table 1. Petrified derivational prefixes in Ewaw.

for example, Yamdena (Toni Mettler and Hedi Mettler 1990), Selaru (David Forrest Coward 1990), and in the Southwest Maluku regency (for instance, Southeast Babar (Hein Steinhauer 2009) and Leti (Van Engelenhoven 2004).

${ }^{15}$ This term was coined by Travis (1997: 11).

${ }^{16}$ Hageman also mentions incidental cases in Geurtjens (1921a) in which processual $f$ - (no. 8 in Table 1) combines with adjectivizing ka- (no. 14, in Table 1) or nga- (no. 15, Figure 1), as for example na-f-ka-nimu-n (3sG-PROC-ADJ-whole-NOM) 'it coagulates' (Geurtjens 1921a: 77) and naf-nga-hong (3SG-PROC-ADJ-burnt) ‘he is quick tempered' (Geurtjens 1921a:123-124). 
Of these affixes, only adjectivizing war- and nan- (respectively no. 11 and 13 in Table 1) seem to be more or less productive. Hageman quotes Geurtjens (1921a), J. Tetelepta et al. (1985), and Travis (1997) who indicate that war-adds an excessive aspect to the meaning of the root, which can be either nominal or verbal. The examples in (3d) are taken from Hageman (2004: 77).

$\begin{array}{llll}\text { (3d) yata- } & \text { 'liver' } & \text { war-yata-n } & \text { 'covetous' } \\ \text { nifa- } & \text { 'tooth' } & \text { war-nifa-n } & \text { 'quarrelsome' } \\ \text { mina- } & \text { 'grease' } & \text { war-mina-n } & \text { 'fatty' } \\ \text { tea- } & \text { 'faeces' } & \text { war-tea-n } & \text { 'defecating everywhere' } \\ \text { waha- } & \text { 'juice' } & \text { war-waha-n } & \text { 'juicy' } \\ \text { 'ut } & \text { 'louse' } & \text { war-'ut } & \text { 'full with lice' } \\ \text { wu'ut } & \text { 'fish' } & \text { war-wu'ut } & \text { 'abounding in fish' } \\ \text { benau } & \text { 'food' } & \text { war-benau } & \text { 'gluttonous' } \\ \text {-kik } & \text { 'to bite' } & \text { war-kiki-n } & \text { 'snappy' } \\ \text {-angrihi } & \text { 'to talk' } & \text { war-angrihi } & \text { 'talkative' }\end{array}$

Hageman (2004: 76-78) points out that most examples of this prefix are actually found in Geurtjens' (1921b) wordlist. ${ }^{17}$ None of the authors consulted actually indicates to what word class the war- derivation belongs. The English translations in (3d) suggest that they are adjectives. However, Hageman observes that, when they are derived from inalienable nouns, they are intrinsically marked with a possessive suffix when used predicatively as, for example, in war-tumu-m (EXC-body-2sGP) 'you are fat', taken from Travis (1997: 47). Only one example occurs in Geurtjens' (1924) texts, in which it is clearly used adverbially.

$\begin{array}{lllll}\text { Kud-Kudur Yar na-'an } & \text { war-benau-n } & \text { li } & \text { rehe. } \\ \text { Kud-Kudur Yar } & \text { 3SG-eat } & \text { EXC-food-N } & \text { very } & \text { win } \\ \text { 'Kud-Kudur Yar ate extremely gluttonously.' } & \end{array}$

As has been outlined in the box Table 1 above, Hageman's (2004) findings suggest that the three adjectivizing prefixes $k a-, n g a-$, and $m a-$ (no. 14, no. 15, no. 16) are related to the prefixes $f-, n g-$, and $m$ - (no. 4, no. 5, no. 6 ) which create verbs referring to involutional conditions, states, and qualities, or conditions, respectively. Additionally, Hageman found another nominalizing prefix $b a-$ (no. 17), which correlates with the prefix $v-\sim b$ - (no. 17) and also creates verbs referring to conditions.

Many Ewaw lexical morphemes have allomorphs ending either in $-k,-t$, $-n g$, or $-n$. Hageman (2004) found that most instances of $-n g$ occur with the causative prefix $f a$-. These final consonants are reminiscent of what J.C.G. Jonker (1906) refers to as the "anorganic final consonant" suffixes in languages of East Nusantara. As can be seen in Table 2, these suffixes sometimes combine with

\footnotetext{
${ }^{17}$ In his (1921a) grammatical description, Geurtjens mentions three other prefixes, bar-, far-, and fer-which have the same function. Hageman therefore considers them allomorphs of the same morpheme.
} 
one or two prefixes. For the functions of these prefixes, I refer the reader to Table 1. The attested combinations of suffixes and prefixes is fully lexically motivated.

\begin{tabular}{|l|lll}
\multicolumn{1}{l}{ Suffix } & Prefix & \\
& $-k$ & $\varnothing, h a-$ & denominal transitive verb \\
& & $\varnothing, f a-(+t-/ k-), k a-(+f-)$ & causation verb \\
& $-t^{18}$ & $\varnothing, f a-(+n g-)$ & denominal intransitive verb \\
& $\varnothing$ & denominal adjective \\
& $\varnothing$ & transitivization of intransitive verb \\
& $\varnothing,(+$ CV reduplication) & deverbal nominalization \\
3 & $-n$ & $\varnothing$ & nominalization \\
4 & $-n g$ & $\varnothing, f a-$ & verbalization (mostly of inalienable nouns)
\end{tabular}

Table 2. "Anorganic consonant" suffixes in Ewaw.

The orthography used in this article enables us to see that, in a previous stage of the language, the addition of a consonant suffix required disyllabic stems, which became monosyllabic through the metathesis of the nucleus and its onset in the ultimate syllable if this suffix was dropped. However, in speaking practice this is clearly discernable only in the conservative Northern variant of the Mainland Dialect. Its Southern variant displays a complex process of vowel sandhi when a monosyllabic morpheme is created from a disyllabic lexical morpheme by dropping its "anorganic consonant". /a/, which is pronounced as [ə], is raised to [ $\varepsilon$ ] before $/ \mathrm{i} /$ or to [o] before $/ \mathrm{u} / \mathrm{.}$ In the first case / i/ becomes [j], whereas in the latter both vowels merge into [॰.]. Before /i/, / u/ is centralized to $[\gamma]$ and /o/ to [ø] in which both cases /i/ also becomes [j]. Before / u/, /o/ is has a rounded allophone [o], which then merges with $/ \mathrm{u} /$ into [o.]. ${ }^{19}$

In the Island Dialect, however, the vowel of the ultimate syllable is simply dropped when the consonant suffix is deleted. In other words, the vowel in the ultimate syllable is no longer predictable when a consonant suffix is added, as is exemplified in the boxes in (5) by 'be from' and 'leave' versus 'separate (intransitive)' and 'split', and 'wade through something' and 'wade (intransitive)' versus 'sacred' and 'taboo'.

\footnotetext{
${ }^{18}$ In a few instances -t creates nouns which correspond to other nouns without an obvious difference in meaning, for example, mea- $n$ 'shame (N)' versus mea- $t$ 'shame (N)' and maun 'bird' versus manu- ' $^{\mathrm{bird}}$ '

${ }^{19}$ No instances of metathesis have been found in which /i/ precedes / $\mathrm{u}$ / or /o/.
} 
(5)

'be from'
'leave'
'separate (intr.)'
'split, decide'
'bird'
'bird'
'wade through s.th.'
'wade (intr.)'
'sacred'
'taboo'
'sit'
'repair'

\begin{tabular}{|c|c|c|c|}
\hline Zwolle spelling & I & $\mathbf{N}$ & $\mathrm{S}$ \\
\hline $\begin{array}{l}\text {-tail } \\
\text {-tali-k }\end{array}$ & $\begin{array}{l}\text {-tal } \\
\text {-tali-k }\end{array}$ & $\begin{array}{l}\text {-tajl } \\
\text {-tali-k }\end{array}$ & $\begin{array}{l}-t \varepsilon j l \\
-t ə l i-k\end{array}$ \\
\hline $\begin{array}{l}\text {-ham } \\
\text {-hama-k }\end{array}$ & $\begin{array}{l}\text {-ham } \\
\text {-hama-k }\end{array}$ & $\begin{array}{l}\text {-ham } \\
\text {-hama-k }\end{array}$ & $\begin{array}{l}\text {-həm } \\
\text {-həmə-k }\end{array}$ \\
\hline $\begin{array}{l}\text { maun } \\
\text { manu-t }\end{array}$ & $\begin{array}{l}\text { man } \\
\text { manu-t }\end{array}$ & $\begin{array}{l}\text { maun } \\
\text { manu-t }\end{array}$ & $\begin{array}{l}\text { mo.n } \\
\text { mənu-t }\end{array}$ \\
\hline $\begin{array}{l}\text {-lur } \\
\text {-luru-t }\end{array}$ & $\begin{array}{l}\text {-lur } \\
\text {-luru- } t\end{array}$ & $\begin{array}{l}\text {-lur } \\
\text {-luru-t }\end{array}$ & $\begin{array}{l}\text {-lur } \\
\text {-luru-t }\end{array}$ \\
\hline $\begin{array}{l}\text { muil } \\
\text { muli-n }\end{array}$ & $\begin{array}{l}\text { mul } \\
\text { muli-n }\end{array}$ & $\begin{array}{l}\text { mujl } \\
\text { muli-n }\end{array}$ & $\begin{array}{l}\text { mrjl } \\
\text { muli-n }\end{array}$ \\
\hline $\begin{array}{l}-d o u k \\
\text {-fa-doku-ng }\end{array}$ & $\begin{array}{l}-d o k \\
-f a-d o k u-n g\end{array}$ & $\begin{array}{l}-d o . k \\
-f a-d o k u-n g\end{array}$ & $\begin{array}{l}-d o . k \\
-f \partial-d o k u-n g\end{array}$ \\
\hline
\end{tabular}

Hageman (2004) traces the origin of Ewaw $-k$ to Proto Malayo-Polynesian *-aken, which Blust (2003: 472) describes as a benefactive suffix. Although Hageman (2004) found them in the closely related language of Fordata as well, the origins of the Ewaw - $n g$ and - $t$ remain unclear. A first look at nominalizing $-n$ might suggest that it is related either to Proto Malayo-Polynesian * $\tilde{n} a$ ' $3 S_{G}$ ', as was also suggested by Jonker (1906) for the same suffix in Uab Meto on Timor Island, or to *-an, with which deverbal nouns of location were created in Proto Malayo-Polynesian (Blust 2003: 472).

Reduplication is the only productive morphological device in Ewaw and has been attested in verbs, nouns, adjectives, and numerals. Monosyllabic morphemes are fully reduplicated, unless the onset and the coda are the same, in which case the reduplication prefix is $\mathrm{CV}$ as, for example, in ror 'to grill' $\rightarrow$ ro-ror 'grilled'. Polysyllabic morphemes reduplicate the penultimate syllable and the onset of the ultimate syllable. If the onset of the ultimate syllable is a glottal stop or fricative, the reduplication prefix is CV as, for example, in si'an 'bad' $\rightarrow$ si-si'an 'very bad' and raha 'polish' $\rightarrow$ ra-raha 'polishing stone'. If the ultimate syllable lacks an onset, both the penultimate and ultimate syllables are reduplicated as, for example, in hoar 'sew' $\rightarrow$ hoar-hoar 'sewn, stitched'.

Table 3 shows that reduplication can encode three aspectual or modal meanings to a verb. On adjectives it marks only the intensive mode. Reduplication on nouns and numerals mark diversity. ${ }^{20}$

\footnotetext{
${ }^{20}$ With reference to J. Rijkhof's (1991) proposal for nominal 'aspect', the meaning of 'uncontrolled' or 'unspecified' action might very well be the verbal counterpart of the nominal 'aspect' diversity, which enables the set of aspects to be brought back to three.
} 


\begin{tabular}{|l|c|c|c|c|}
\hline \multirow{4}{*}{ Word class } & \multicolumn{4}{|c|}{ Semantic load } \\
\cline { 2 - 5 } & intensity & duration & 'uncontrolled' & diversity \\
\cline { 2 - 5 } ADJ & X & X & X & \\
N & X & & & $X$ \\
NUM & & & & $X$ \\
\hline
\end{tabular}

Table 3. Reduplication in Ewaw.

Example (6a) shows that reduplication is also used as a means to derive nouns and adjectives from verbs. The final example wir-waruk 'dispersed' shows an instance of reduplication plus vowel change of /a/ into /i/. ${ }^{21}$

\begin{tabular}{|c|c|c|c|c|c|}
\hline Input & & & Output & & Derivation \\
\hline douk & 'sit' & $\rightarrow$ & douk-douk & 'dwelling place' & \\
\hline sikar & 'sing' & $\rightarrow$ & sik-sikar & 'song' & noun \\
\hline teik & 'draw (water)' & $\rightarrow$ & teik-teik & 'bucket' & \\
\hline lewan & 'roast' & $\rightarrow$ & lew-lewan & 'roasted' & \\
\hline wutut & 'pluck' & $\rightarrow$ & wut-wutut & 'plucked' & adjective \\
\hline wasil & 'lie' & $\rightarrow$ & was-wasil & 'lying' & \\
\hline welak & 'turn' & $\rightarrow$ & wel-welak & 'turning' & adverb \\
\hline waruk & 'disperse' & $\rightarrow$ & wir-waruk & 'dispersed' & \\
\hline
\end{tabular}

Together with the verb welak 'turn', waruk 'disperse' exemplifies accidental cases of deverbal adverbialization through reduplication. Sentence (6b) displays the use of the latter adverb in a clause.

$$
\begin{aligned}
& \text {... n-taha wel-welak wail afa besa rahan raa- } n \text {. } \\
& \text { 3SG-grab RED-turn again thing all house inside-3SGP } \\
& \text { '... he knocked everything around in the house." (Boketsin: } 73 \text { ) }
\end{aligned}
$$

\section{SYNTAX: DeIXIS AND VERB SERIALIZATION}

Possession is encoded by means of possessive suffixes on the possession noun (Section 2, example (3b)) which can be directly preceded by the possessor noun. As was already hinted at by raa- $n$ (inside-3sGP) in example (6b) in the previous section, locative information is similarly encoded mainly by means of a possessive phrase in which the location noun is marked as a possession and is preceded by the noun referring to the landmark as a possessor noun.

Ewaw is a typical East-Indonesian language having an SVO word order. Since it lacks genuine prepositions and a passive voice, Ewaw also uses a

${ }^{21}$ Reduplication with vocalic changes are lexically defined and always imply a change to /i/. Lack of space prevents us from elaborating here on whether in this specific example the reduplication's prefix wir- is derived from the segment war in waruk or from its monosyllabic allomorph waur (> waru-k). 
transitive construction with monovalent verbs. This is exemplified in (7a) in which the monovalent -douk'sit' is directly followed by a nominal compliment habo 'boat', comparable to the nominal complement sair ain (hut one) 'a hut' of the bivalent verb -out 'make, do' in (7b).

$$
\begin{aligned}
& \text {... ya-douk habo ... } \\
& \text { 1SG-sit boat } \\
& \text { '... I sat down in the boat ...' } \\
& \text { (Ngimas: } 31 \text { ) }
\end{aligned}
$$

$$
\begin{aligned}
& \ldots h i=r \text {-'out sair ain ... } \\
& \text { 3PL=3PL-do hut one } \\
& \text { '... they made a hut ...' } \\
& \text { (Lorar: } 36 \text { ) }
\end{aligned}
$$

The transitive construction with a "location object" as in (7a) imposes a construal in which the location is closely connected to the profiled event. Ewaw uses a morpheme na ' $\mathrm{LOC}^{\prime}$ to create a clause in which the location is construed in a less intimately connected way to the profiled verbal action or state and its participants. Its unmarked slot is after the predicate, as exemplified in (8a), although it can be relocated to clause initial position as a topic. We hypothesize that this $n a$ has been grammaticalized from $n a^{\prime} a$ 'exist' (example $8 \mathrm{c})$, which has never been attested, with a nominal complement. We follow Geurtjens (1921a: 48) who labels $n a^{\prime} a$ 'exist' a verb, even though it is the only one in Ewaw which is not inflected for person. ${ }^{22}$

$\begin{array}{lllll}\text { (8a) } \quad \begin{array}{l}I=n-l i^{\prime} i k \\ \text { 3SG=3SG-see }\end{array} & \text { skin-3SGP } & \text { ngawan } & \text { na } & \text { uran } \ldots \\ & \text { reflection } & \text { LOC } & \text { wok }\end{array}$

'She saw the reflection of her skin in the (water of) the wok.' (Lorar: 44)

(8b) Rahan na'a wuk te waid?

house exist also or NEG

'Is there also a house, or not?' (Raut ni hoan ain fit: 50)

The only morpheme in Ewaw which classifies for a genuine prepositional status is wei, glossed here as 'BEN', which marks an addressee (8c) or a (candidate) recipient (8d). Unlike $n a$ 'LOC', however, wei phrases are only attested after the predicate. Consultants were generally very reluctant to relocate it to clause initial position (8e).

$$
\begin{array}{llll}
\ldots \text {.. su=r-nai-tuil } & \text { wei } & \text { teran } & \text { raut. } \\
\text { down=3PL-say-tell } & \text { BEN lady } & \text { King }
\end{array}
$$

'... they went to tell (it) to the queen.' (Wair Watat Hir Ru: 17)

\footnotetext{
${ }^{22}$ Its counterpart in its close co-gener Fordata in the Tanimbar Archipelago is still fully inflected (P. Drabbe 1932: 66). Geurtjens (1921a: 28) mentions norang 'follow' as another example of a verb which is not inflected in Ewaw. He concludes that this verb has a petrified 3sG prefix n-, whereas Fordata still has the full inflection paradigm.
} 
(8d)

Waut Sin Kilwat i=n-ham wu'ut wei umat ngaled besa ...

W.S.K. 3SG=3SG-divide fish BEN people many all

‘Waut Sin of Kilwat has divided fish among everybody ...” (Butri Waut Rew: 12)

(8e) *Wei umat ngaled besa, Waut Sin Kilwat i=n-ham wu'ut.

DIR people many all W.S.K. 3SG=3SG-divide fish

Ewaw deixis combines a positional and a dimensional system. Whereas in the first-mentioned the Speaker is the deictic centre from which to localize the referent, in the latter it is the shore and the East-West trajectory of the sun through which the position of the narrated participants is determined with respect to the speech participants. Table 4 provides a list of deictic markers.

\begin{tabular}{|l|l|lll|l|}
\hline Pronoun & unmarked & $i$ & $\leftarrow \rightarrow$ & he ke & emphatic \\
\hline Adverb & there & ro'oi & $\leftarrow \rightarrow$ & weil & beyond/yonder \\
& north/under & waw & $\leftarrow \rightarrow$ & wow & south/up \\
\hline \multirow{2}{*}{ Direction verb } & down from Sp. & $s u$ & $\leftarrow \rightarrow$ & rat & up from Sp. \\
& seaward from Sp. & ro & $\leftarrow \rightarrow$ & ra & landward from Sp. \\
& towards Sp. & ma & $\leftarrow \rightarrow$ & ti & away from Sp. \\
\hline
\end{tabular}

Table 4. Ewaw deictic markers. ${ }^{23}$

Unlike most other languages in the region, Ewaw has a one-term positional system (Van Engelenhoven 2010) in which the 3sG pronoun $i$ functions as the unmarked demonstrative pronoun. Geurtjens (1921a: 23) mentions he (Island Dialect) or ke (Mainland Dialect) as its emphatic counterpart. He also observes that, when used in "one word" sentences, these demonstrative pronouns are combined with the classifier ain, ${ }^{24}$ as in ain $i$ (CLAS= 3SG) 'this (one)' (Geurtjens 1921a: 26), ain ke (CLAS EMPH) 'that (one)' (Geurtjens 1921a: 23). The dimensional system uses "adverbs" - to use Geurtjens' terminology - and directional verbs. The "adverbs" occur with noun phrases as deictic markers as, for example, habo weil (boat yonder) 'yonder boat' (Geurtjens 1921a: 23) and as true adverbs with a location particle udan or den as, for example, udan weil (LOC yonder) 'over there' (Geurtjens 1921a: 52). Geurtjens (1921a) observes that the direction verbs can occur uninflected as deictic markers to noun phrases as in his example of rat 'upwards' in (9). In these instances, the sentence clearly profiles a state.

${ }^{23}$ Van Engelenhoven (2000) provides a different deictic schema based on fieldwork in Zwolle (The Netherlands). Here, he makes a distinction between directly Speaker related, same level spatials, and different level spatials related to the position of the Speaker. He mentions two deictics, ya 'near Speaker' and reit '(directly) above Speaker' which are not mentioned elsewhere. Geurtjens (1921a) refers to ya as an emphatic marker rather than a deictic. One other striking difference is that both wow and waw are mentioned with the meaning of 'beneath Speaker' and 'below', respectively. In all other sources, however, wow means 'up' or 'above'. The waw-wow distinction in the Kei Archipelago is related to the North-South axis of Yut Island. Since it did not apply in the Zwolle context, this might have caused this aberrant information.

${ }^{24} \mathrm{He}$ actually refers to ain as a "relative pronoun", which he hypothesizes is related to the 3sG pronominal prefix $(e=) n$. 
(9) Ohoi rat hoib ro-ro
village upward still RED-seaward
'That village up there is still far.' (Geurtjens 1921a: 23)

However, if the sentence profiles a movement, the direction verb is inflected, even if the referent of the marked NP does not move itself. This is exemplified in (10) in which the referent of $d e d=i$ 'that road' is marked for movement towards the sea away from the Speaker, even though its referent cannot move itself.

$\begin{array}{llll}O=m-l i^{\prime} i k=k e n & \text { nung } & \text { af } a=i=n-h o & \text { ded }=i=n-r o ? \\ \text { 2SG=2SG-see=hit } & \text { 1SGP } & \text { thing=DEM=3SG-pass } & \text { road=DEM=3SG-seaward }\end{array}$

a: 'Have you seen something of me pass on that road towards the sea?'

b: 'Have you seen something of me passing seawards along that road?'

(Tum kokat ni: 5)

In Marian Klamer, Ger Reesink, and Miriam van Staden's (2008) typology of serial verb constructions in East Indonesia, sentence (10) ded $=i=n-r o$ (road=DEM=3sG-seawards) could be classified as a co-dependent serialization in which the object of $n$-ho (3sG-pass), ded=i (road=DEM), is the subject of $n$-ro (3sG-seawards). This is conveyed in the translation in a). Alternatively, it can be analysed as an independent serialization in which the subject of $n$-ho (3sG-pass) is also the subject of $n$-ro (3sG-seawards). This is conveyed by the translation in $b$ ).

Possibly, the ambiguity revealed by the translations in (10) is imposed by the verb - $h o$ 'pass' which disallows any additional adverbial modification. Other motion verbs, however, can be modified by the twenty-four adverbial modifiers mentioned in Table 5 . They are mutually exclusive from each other and from the direction verbs mentioned in Table 4 .

Table 5 shows us that these adverbs have different origins and functions. In fact, two of them are derived from nouns: ' $u$ 'forwards' (no. 7) and muir 'backwards' (no. 23). Three of them, non 'fixed' (no. 6), hang 'opposite' (no. 5), and watun 'open' (no. 18) do not appear to have a verbal or adjectival counterpart. ${ }^{25}$ The logic of movement is the reason that the adverbs encoding 'around' dang and yail (no. 8 and no. 9) do not have a counterpart. Whereas the notions "up" and "down" do have adverbial and directional verb counterparts in the deictic set (Table 4), the adverb yaik 'upwards' (no. 10) in Table 5 does not have a counterpart. 'Together' $u k$ (no. 1), on the other hand, has five counterpart adverbs which profile different movements in the opposite direction. Three adverbs, ken 'rightly' (no. 11), sa 'wrongly' (no. 24), and na nai (no. 12) do not encode direction of movement, but rather mode. Non "fixed" (boxed at no. 6) is the only adverb which clearly marks an aspect of permanency.

\footnotetext{
${ }^{25}$ The similarity between watun 'open' (no. 18) and watuk 'away' (no. 17) could suggest that both adverbs originally derive from the same source but have different "anorganic consonant suffixes" (see Table 2).
} 


\begin{tabular}{|c|c|c|c|c|c|c|c|c|}
\hline & $\mathrm{V} / \mathrm{N}$ & Adv & & & & Adv & $\mathrm{V} / \mathrm{N} / \mathrm{ADJ}$ & \\
\hline 1 & 'collect' & 'together' & $u k$ & $\leftarrow \rightarrow$ & $\begin{array}{l}\text { rik } \\
\text { ham } \\
\text { we'ak } \\
\text { haling } \\
\text { watuk }\end{array}$ & $\begin{array}{l}\text { 'apart' } \\
\text { 'separate' } \\
\text { 'to pieces' } \\
\text { 'asunder' } \\
\text { 'away' }\end{array}$ & $\begin{array}{l}\text { 'divide' } \\
\text { 'divide' } \\
\text { 'break' } \\
\text { 'different' } \\
\text { 'fling' }\end{array}$ & $\begin{array}{l}13 \\
14 \\
15 \\
16 \\
17\end{array}$ \\
\hline 2 & 'shut' & 'block' & noit & $\leftarrow \rightarrow$ & watun & 'open’ & -- & 18 \\
\hline 3 & 'reach' & 'till' & harang & $\leftarrow \rightarrow$ & toik & 'miss' & 'fail' & 19 \\
\hline $\begin{array}{l}4 \\
5\end{array}$ & 'follow' & $\begin{array}{l}\text { 'along' } \\
\text { 'opposite' }\end{array}$ & $\begin{array}{l}\text { norang } \\
\text { hang }\end{array}$ & $\begin{array}{l}\leftarrow \rightarrow \\
\leftarrow \rightarrow\end{array}$ & $\begin{array}{l}\text { lauk } \\
\text { ‘il }\end{array}$ & $\begin{array}{l}\text { 'passed' } \\
\text { 'backwards' }\end{array}$ & $\begin{array}{l}\text { 'loosen' } \\
\text { 'return' }\end{array}$ & $\begin{array}{l}20 \\
21\end{array}$ \\
\hline 6 & -- & 'fixed' & non & $\leftarrow \rightarrow$ & talik & 'off' & 'leave' & 22 \\
\hline $\begin{array}{l}7 \\
8 \\
9 \\
10\end{array}$ & $\begin{array}{l}\text { 'head' } \\
\text { 'encircle' } \\
\text { 'encircle' } \\
\text { 'lift' }\end{array}$ & $\begin{array}{l}\text { 'forward' } \\
\text { 'around' } \\
\text { 'around' } \\
\text { 'upward' }\end{array}$ & $\begin{array}{l}\text { 'u } \\
\text { dang } \\
\text { yail } \\
\text { yaik }\end{array}$ & $\leftarrow \rightarrow$ & muir & 'backwards' & 'back' & 23 \\
\hline 11 & 'hit' & 'rightly' & ken & $\leftarrow \rightarrow$ & $s a$ & 'wrongly' & 'wrong' & 24 \\
\hline 12 & 'give' & 'can' & $n a \sim n a i^{26}$ & & & & & \\
\hline
\end{tabular}

Table 5. Sets of adverbial markers in Ewaw.

The first part of sentence (10), $o=m$-li'ik=ken (2sG=2sG-see=hit) 'you have seen' classifies in Klamer, Reesink, and Van Staden's (2008) typology as a dependent serialization, which is a serial verb construction in Ewaw, with only the first verb inflected for subject agreement while both verbs share the same subject. In the same article, they also observe that co-dependent serialization - a serial verb construction in which the object of the first verb is simultaneously the subject of the second verb - is not a very regular pattern in East Nusantara. However, it is very frequent in Ewaw. An example of codependent serialization is once more provided in example (11a) in which waut 'stone' is the object of m-tew 'you throw' and at the same time the subject of $n$ - $b a$ 'it goes'.

$$
\begin{array}{llll}
\mathrm{O}=m \text {-tew } & \text { waut } & n-b a & b u d u
\end{array}
$$

The adverbial use of a verb co-determines the choice of the object. Whereas in (11a) the goal of the verbal act 'throwing', budu 'bottle', is encoded as the object of $n$-ba 'he goes', in (11b) the adverbially used verb toik 'miss' in the dependent serial construction requires the object to profile the goal.

\footnotetext{
${ }^{26}$ Geurtjens (1921a: 39, 49) supposes that $n a$, which he systematically writes as naa and labels "potential auxiliary", derives from $n a^{\prime} a$ 'exist'. Since intervocalic *1 was generally lost in Ewaw, we suggest it might instead be the third person singular inflection of the verb 'give', $n-a\left(<{ }^{*} n\right.$-ala 'he gives'), which is used adverbially. In this scenario, Ewaw links up with other Southeast and Southwest Malukan languages, for example, Fordata (Drabbe 1926a) and Leti (Van Engelenhoven 2004), in which 'give' is used in exactly the same way.
} 
(11b)

$O=m$-tew $=$ toik $\quad$ budu.

2SG=2SG-throw=miss bottle

'You miss the bottle (for example, you threw a stone at the bottle, but it did not reach it).'

Consultants were reluctant to add the theme waut 'stone' in (11b). When using lauk 'pass', the theme 'stone' can be encoded as the object of the verb n-houw 'it accompanies', resulting in another co-dependent serialization.

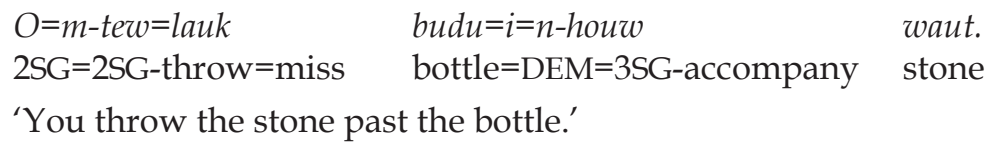

Geurtjens (1921a) and Ed Travis (1997) confirm that the verb -houw in its full lexical meaning of 'accompany' still has the full paradigm of pronominal inflection, for instance, $y a^{\prime}=u-h o u w=o$ (1sG=1sG-accompany=2sG) 'I accompany you' (Geurtjens 1921a: 59) or $i=t-h o u w=i$ (1PLINC=1PLINC-accompany=3sG) ‘we accompany him' (Travis 1997:32). In its grammaticalized function, it is always inflected for 3sg while its object encodes either an instrument as in (11c), or a comitative participant as in (11d).

$$
\begin{aligned}
& \text {... o=m-douk i=n-houw hir waid,... } \\
& \text { 2SG=2SG-sit 3SG=3SG-accompany 3PL NEG } \\
& \text { '... you do not sit with them, ...' (Raut bod-bod: 47) }
\end{aligned}
$$

Whereas Hageman (2004) correctly identifies remnants of a causative morphology in Ewaw (see Tables 1 and 2), the productive strategy to encode causation is by means of a combination of clauses in which the first features the verb 'out 'make' and the second features the verb which profiles the event caused (whether this be an action or a state). Example (12a) shows that both clauses are linked by means of a purposive sequential fo, in which case the second clause contains a transitive construction. However, example (12b) shows that both clauses are juxtaposed into a co-dependent serial verb construction when the second clause contains an intransitive construction. In both examples, the clause borders are indicated by square brackets in the gloss line.

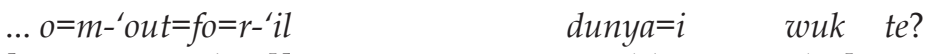

$$
\begin{aligned}
& {[2 \mathrm{SG}=2 \mathrm{SG}-\mathrm{make}=][\mathrm{PUR}=3 \mathrm{PL}-\text { return world }=\mathrm{DEM} \text { also }] \text { or }} \\
& \text { '... you make them return to the world, do you?' (Ko wat hir ru: 40) }
\end{aligned}
$$


Aid=bo koit hi=r-'out kalbatu hi=r-reak

[then=SEQ child 3PL=3PL-make] [coconut.leaf.vein 3PL=3PL-decorated]

$i=n$-houw nur ihi-n.

[3SG=3SG-accompany coconut contents-3SGP]

'And then children had decorated the coconut leaf veins with pieces of coconut meat.' (literally, made the coconut leaf veins be decorated with pieces of coconut meat ${ }^{27}$ ) (Toum nifmas ohoi le'en ni: 31 )

Ewaw uses independent serial constructions with the posture verbs 'sit', 'lie', and 'stand' in the first clause to add a static aspect to the event profiled in the second clause. Of these three verbs, 'stand' (example 13a) has been attested the least, whereas 'sit' (example 13b) is attested the most. Sentence (13c) contains an example of 'lie'.

$$
\begin{aligned}
& \mathrm{Na}={ }^{\prime} u, \quad i=n \text {-dir } \quad i=n \text {-bein=wat } \quad n a=h a b o={ }^{\prime} u \text {. } \\
& \text { LOC=head } 3 S G=3 S G-\text { stand } \quad 3 S G=3 S G-\text { dance=bit } \quad \text { LOC=ship=head }
\end{aligned}
$$

'At the front, she was dancing a bit on the bows of the ship.' (Lur lim: 19)

$$
\begin{aligned}
& \text {...noit } i=n \text {-bein, } \quad i=n \text {-douk } \quad i=n \text {-bein=wat. } \\
& \text { wind } 3 S G=3 S G-\text { dance } \quad 3 S G=3 S G-\text { sit } \quad 3 S G=3 S G-\text { dance=bit }
\end{aligned}
$$

'... if the wind blew, it (the pole) was swaying a bit.' (Butri bulan bernam: 49)

$$
\begin{array}{llll}
I=n-t u b & i=n-k a n e a k & \text { umat } & \text { kasil } \\
\text { 3SG=3SG-lie } & \text { 3SG=3SG-spy } & \text { human } & \text { lizard } \\
i=n \text {-out='il=fo=umat. } & & \\
\text { 3SG=3SG-make-return=SEQ=human } &
\end{array}
$$

'She was spying on how the lizard man would turn back into a human.' (Kasil mas-mas: 22)

'Stand', 'sit', and 'lie' are mutually exclusive with 'go' [note: I'm not sure since I am not a native speaker of English] which signals a "prospective" aspect (example 13d). The latter strategy is attested in most languages in East Nusantara. Example (13e) from the same text shows that, alternatively, the same aspect can be encoded by means of the direction verb su 'downwards from Speaker' (glossed as 'down'), which is not inflected for person. As all verbs cliticize each other, the underlined words in this example might look like a co-dependent serial construction in which only the first verb is inflected. The imperative in (13f), however, shows that $s u$ functions uninflected on the syntactic level as a grammatical particle to signal the "prospective" aspect. On the phonotactic level, it simultaneously provides the syllable to which the subject agreement marker can cliticize as a coda instead of the otherwise required subject clitic 0 '2SG' ${ }^{28}$

\footnotetext{
${ }^{27}$ Consultants were reluctant to use the causative verb $f a-b$-rea- $t$ (caus-cond-decorate-t) here, since it requires human subjects and objects, for example, $h i=r$-fabreat $=i(3 \mathrm{PL}=3 \mathrm{PL}-$ decorate $=3 \mathrm{SG})$ 'they decorate him' versus ?hi=r-fabreat kalbatu (3PL=3PL-decorate coconut.leaf.midrib) 'they decorate coconut leaf midribs'.

${ }^{28}$ For an elaboration on subject agreement prefixes being codas in Uab Meto (West Timor) and
} 

(13d) Leran ko ain i=n-ba na-fngihun ...
once kid one 3SG=3SG-go 3SG-tap.toddy
'A boy went to tap toddy ...' (Lour hir ru arat: 2)
$\begin{array}{lllll}\text { Aid }=b o & \text { koit } & i=n-r o n=s u=n \text {-tuil } & \text { vei } & \text { rena- } n \text {. } \\ \text { then=SEQ } & \text { child } & \text { 3SG=3SG-cry=down=3SG-tell } & \text { DIR } & \text { mother-3SGP }\end{array}$
'And then the child went to tell it crying to his mother.' (Lour hir ru arat: 40)
Hi=r-nai: "Su=m bua=m-hauk!"
3PL=3PL-say down=2SG $\sim$ go=2SG-want
'They said: “Go look for her!"' (Raut ni hoan ain fit 1: 74)

\section{DisCUSSION: EWAW COMPARED WITH ITS NEIGHBOURS IN THE REGION}

In the ongoing discussion on the isolating tendencies of languages in the Lesser Sunda Islands (for example, David Gil and Antoinette Schapper (eds) 2020), Ewaw's typology appears to be misplaced. Even when its syntactic typology is compared to those of neighbouring languages which are either closely related (as are Fordata and Yamdena on Tanimbar Island) or remotely related (as are the Central Malukan language of Banda spoken on Yut Island and Dobel in the Aru Archipelago), Ewaw looks quite unusual. A question mark in the table below indicates that no information on the topic could be retrieved from the sources consulted.

$\begin{array}{llllll} & \text { Fordata } & \text { Ewaw } & \text { Yamdena } & \text { Dobel } & \text { Banda } \\ \text { noun classes } & 2 & 2 & 2 & 2 & 2 \\ \text { nominal classifiers } & 1 & 14 \rightarrow 3 & 1 \rightarrow 0 & 11 & 0 \\ \text { verb classes } & 3 & 4 & 2 & 3 & 6 \\ \text { demonstratives } & 3 & 2 \rightarrow 12 & 3 & 12 & 2 \\ \text { directional verbs } & 12 & 6 & 3 & 2 & 2 ? \\ \text { dependent verb serialization } & 14 & 24 & 0 & 10 & ? \\ \text { "genuin" prepositions } & 1 & 1 \rightarrow 2 & 2 & 3 & 4 \\ \text { types of relative clauses } & 2 & 2 \rightarrow 0 & 0 & 3 & 0 ?\end{array}$

Table 6. Ewaw's typology compared to some of its neighbours in the region.

All languages distinguish two noun classes, alienable and inalienable, which can be specified again for animateness or inanimateness in Dobel by means of a nominal classifier in counting. Geurtjens (1921a) mentions fourteen classifiers in Ewaw, of which Van Engelenhoven (2002) has observed that only three were recognized by consultants in Zwolle: $u$ for boats, wat $u$ for globular objects, and the general classifier ain. Fordata and Yamdena have only one, which in the latter is obligatory only if the numeral is used independently without a noun (Drabbe 1926b: 26). Banda does not appear to have any nominal classifier.

Meher (Southwest Maluku), see Van Engelenhoven 1993. 
Although not distinguishing between animate and inanimate nouns, around 1921 Ewaw's classifier system looked like the complex systems which are now still attested in Aru languages like Dobel.

Its one-term deictic system seems to distinguish Ewaw from its neighbours. Like Banda, it has two demonstratives. In Ewaw, however, one of the demonstratives is only used emphatically in oppositions ("thát one, not this one"). Fordata, Yamdena, and Dobel make a tripartite distinction between near, not near the Speaker, and far from the Speaker, to which Dobel adds a singular-plural distinction and a separate set for mass nouns. The latter language therefore distinguishes twelve demonstratives whereas Fordata and Yamdena only have three. Ewaw's set of two demonstratives is expanded into a deictic system of twelve markers by four adverbs and six direction verbs. Their cognates in Fordata all fall into the category of directional verbs, which implies that Fordata has two deictic verbal morphemes more than Ewaw. The system in Yamdena is simpler than those in Fordata and Ewaw. The counterparts of "under" and "up", which are verbs in Fordata and adverbs in Ewaw, respectively, are nouns in Yamdena.

Although Fordata has the most directional verbs of all the languages in Table 6, Ewaw has far more combinations for dependent serial verb constructions (listed as adverbial markers in Table 5). The three directional verbs in their co-gener Yamdena, on the other hand, are always inflected and combine in independent rather than dependent serializations. The fifteen prepositions in Dobel which Hughes (2000: 160, Figure 18) proposes are all derived from verbs. Thirteen of them still have a "cognate verb" counterpart of which two - "go/towards" and "come from/from" have clear counterparts in Ewaw, Fordata, and Yamdena. ${ }^{29}$

The number of verb classes based on their subject agreement paradigms are comparable in Ewaw, Fordata, Yamdena, and Dobel. In Fordata and Dobel there are two one-member classes. In Yamdena there is only one class with one member, while in Ewaw there are three one-member classes. Collins and Kaartinen (1998) report six conjugation classes for Banda, but indicate that there might be many more. It also has the most conservative verbal paradigms of all Central-Malukan languages. Interestingly, Donohue (2004) observes that the languages in Central Maluku and the Aru Archipelago display a split-intransitive alignment system, which none of the Southeast Malukan languages appears to have. ${ }^{30}$

Of all languages, Banda has the most "genuine" prepositions in that they seem not to be related to verbs and never occur inflected for subject agreement.

\footnotetext{
${ }^{29}$ Since Hughes (2000) clearly signals that "sometimes it is difficult to tell whether we have a preposition or whether we have a serial verb construction", we surmise that actually these prepositions are uninflected verbs in dependent serial verb constructions in the sense of Klamer, Reesink, and Van Staden (2008).This is supported by Hughes' remark in footnote 45 on the same page in which he states that the cognates of the Dobel prepositions in other Aru languages, like Tarangan, still inflect as verbs.

${ }^{30}$ Donohue's (2004) analysis of the Selaru system as split-intransitive therefore supports Mills' (1991) observation of Selaru's aberrant position among the Tanimbar languages.
} 
O. Kakerissa, Ny.J. Kasihuw and J. Tamaela (1996: 30) report that Banda uses the preposition wa for both the allative and ablative notion, which is exactly what Hughes (2000: 160) signals for the Dobel verb -bana. A possible exception might be the comitative preposition which Kakerissa, Kasihuw and Tamaela (1996: 30) list for Banda: how. It looks like a loan from the Ewaw verb -houw, albeit it is not inflected for subject agreement, whereas it is inherently inflected for 3sG in its comitative and instrumental uses in Ewaw. Its cognates in Fordata and Yamdena on the other hand always occur in independent serializations in that they share the same subject agreement as the preceding verb. All three Southeast Malukan languages have the same benefactive preposition. A comparison shows that in Fordata "exist" is still fully inflected when it is used as a locative marker. In Ewaw it is the only verb which is no longer inflected and has a monosyllabic allomorph which functions as a marker in locative phrases. In Yamdena it has become a true preposition.

Dobel distinguishes three types of relative clause by means of a relative marker and reduplication of the verb. Among the Southeast Malukan languages only Fordata still seems to mark relative clauses by means of special marker which has different forms for singular and plural head nouns. The petrified prefixes in Ewaw with which agent nouns and goal adjectives are derived from verbs seem reminiscent of relativization strategies which might have existed in a previous stage of the language. In Yamdena, and also possibly in Banda, there is no indication of relativization.

Table 7 compares the derivational morphology in the three Southeast Malukan languages. The incredible amount of seventeen derivational prefixes sets Ewaw apart from any language in the region in that no other seems to have so many of them.

$\begin{array}{llll} & \text { Fordata } & \text { Ewaw } & \text { Yamdena } \\ \text { Prefixes } & 8 & 17 \rightarrow 2 ? & 9 \rightarrow 6 ? \\ \text { Infixes } & 1 & 0 & ? \\ \text { Suffixes } & 4 \rightarrow 2 & 4 \rightarrow 0 & ?\end{array}$

Table 7. Derivational affixes in the Southeast Malukan languages.

Even if we adopt Hageman's (2004) thesis that the adjectivizing prefixes $k a-$, $n g a-$, and $m a-$, and the nominalizing prefix $b a$ - are related to the verbal prefixes $k-, n g_{-}, m_{-}$, and $v_{-} \sim b_{-}$, respectively, the remaining number is still an astonishing thirteen (see Table 1). Drabbe (1926a, 1926b) mentions seven of them with similar functions in Fordata and Yamdena: fa-, ba- (mba- in Yamdena), ka-, sa-, $t a-, m a-$, and $n g a$. Hughes (2000) mentions a $r$ - prefix in Dobel which is partly comparable to the one in Ewaw. In Ewaw, however, all prefixes are petrified, with the possible exception of the adjectivizing war- and nan- (no. 11 and no. 13 in Table 1) whereas only three seem no longer productive in Yamdena. In Fordata all are still productive. Finally, Ewaw still has another five prefixes which are not found in any of the other languages. 
Hageman (2004) also observes that Fordata has the same number of derivational suffixes, or "anorganic final consonants", as Ewaw. Craig Marshall (2000: 212) reports that two of them still are productive in Fordata causative morphology. He also mentions an infix, of which we are not aware that something similar exists in Ewaw or Yamdena.

A phenomenon already attested by Drabbe (1926a, 1926b) is the combination of two prefixes deriving causative and intransitive verbs in Fordata and Yamdena, respectively. Hageman (2004) only mentions ka-fand $k a-s$ - in Ewaw, which derive intransitive verbs. A quick browse through Geurtjens' (1921b) 2,064 wordlist results in eleven combinations which derive intransitive verbs (upper box in Table 8) and transitive verbs (lower box in Table 8), respectively.

\section{Fordata}

$$
\begin{array}{l|l}
k a \text { (caus. })+m a \text { (quality) } & f a \text { (causative) }+k a \text { (condition) } \\
f a \text { (causative) }+t a \text { (completion) } \\
f a \text { (causative) }+r a \text { (accident) } \\
f a \text { (causative) }+b a \text { (condition) } \\
f a \text { (causative) }+n g a \text { (state) }
\end{array}
$$

\section{Yamdena}

$t a$ (posture) $+m a$ (adjective) $t a$ (posture) $+k a$ (adjective)

ta (posture) $+r a(?)$

Table 8. Combinations of derivational prefixes in Southeast Malukan languages.

Interestingly, whereas Fordata has only one combination of a causative and a quality prefix, Ewaw shows five combinations of the causative prefix and several intransitive prefixes. On the other hand, whereas Yamdena has three combinations of a prefix ta- - which according to Drabbe (1926b: 56) signals "posture" - with three other intransitive prefixes, Ewaw has six combinations of intransitive prefixes, of which only one has ta-, although its function seems different here.

Although it is not entirely clear from the sources used whether the prefix combinations are still productive in Fordata and Yamdena, it is clear that they have become completely obsolete in Ewaw. Travis (1997) mentions two instances (example 14) in which the combination kaf of the prefix $k(a)$-marking a non-volitional condition and $f$-marking a process optionally occurs as $f a k$, which should be analysed as the causative prefix $f a$ - and the vowelless allomorph of $k(a)-.^{31}$ Whereas the homophony of the prefixes marking causation

\footnotetext{
${ }^{31}$ The presence or absence of a vowel in a prefix has a prosodic and phonotactic basis, which is beyond the topic of the present article.
} 
and process might cause the speaker confusion, the use of the otherwise intransitivizing prefix $k(a)$ - marking a non-volitional condition in a transitive syntactic setting, suggests a stage in Ewaw in which the combinations kaf and fak were interpreted as allomorphs of a single prefix. Geurtjens (1921a: 25) considers kaf- to be a single prefix to mark reciprocity while Travis (1997:39) analyses it as signalling a continuous action. Similarly, Geurtjens (1921a: 67) understood the combination of the prefixes $\mathrm{ka}$ - and s- respectively marking non-volitional and temporary conditions as an adjectivizing prefix, whereas according to Travis (1997: 43) it was a prefix signaling 'entire involvement'.

\begin{tabular}{|c|c|}
\hline base: loi & 'hang' \\
\hline ka-f-loi-k & 'hang (something)' \\
\hline $\begin{array}{l}\text { COND-PROC-hang-CAUS } \\
\text { fa-k-loi }\end{array}$ & 'hang (something)' \\
\hline $\begin{array}{l}\text { CAUS-COND-hang } \\
\text { base: leak }\end{array}$ & 'carry' \\
\hline ka-f-leak & 'hide (something)' \\
\hline $\begin{array}{l}\text { COND-PROC-carry } \\
\text { fa-k-leak } \\
\text { CAUS-COND-carry }\end{array}$ & 'hide (something)' \\
\hline
\end{tabular}

Another difference with the surrounding languages is that Ewaw is the only language with clause final negation (see example (11d)). The nearest language of which we are aware which has clause final negation is the Central Malukan Gorom language, spoken outside the regency in East Seram and on the Seram Laut Islands (Svetlana F. Chlenova 2010). Whereas it is possible that this phenomenon originates from contact with East Seram languages, we prefer to suggest that clause final negation in Ewaw has been triggered by the obvious process of the simplification of its grammar. By having a negator slot at the end of the clause, Ewaw can use the same morpheme hoib (glossed in the examples below as "still") to indicate that the event described is either still ongoing (example 15a) or has not yet begun (example 15b).

$$
\begin{aligned}
& \text { Hoib } \quad i=n \text {-douk }=i=n \text {-fikir ... } \\
& \text { still } \quad 3 \text { SG=3SG-sit=3SG=3SG-think } \\
& \text { 'He was still thinking ...' } \\
& \text { (Raut bod-bod: } 39 \text { ) }
\end{aligned}
$$

$$
\begin{aligned}
& Y a^{\prime}=u \text {-li'ik=rehe hoib. } \\
& \text { 1SG=1SG-see=win still } \\
& \text { 'I have not found it yet.' } \\
& \text { (Lorar: } 30 \text { ) }
\end{aligned}
$$

\section{CONCLUSION}

McWhorter's (2011) simplification theory of the languages in the larger Timor region leans heavily on Hull's (1998) Proto Santalic hypothesis which postulates that the ancestor language of the Austronesian languages of East Sumbawa, Sumba, and Flores, of Timor Island and of South Maluku was originally located in Southeast Sulawesi from where it spread to Timor and the islands around it. It must be noted, however, that Hull himself considered his hypothesis to be a preliminary proposal, which he adapted in later publications (Hull and 
Branco 2002/3; Hull 2004). Especially the "out of Sulawesi" scenario and the "Ambonic superstratum" hypothesis for Timor languages were received with much scepticism by Austronesianists, albeit mostly in spoken discourse. ${ }^{32}$ The close genetic link between the East Group languages in Timor and the Luangic-Kisaric in Southwest Maluku was identified by Van Engelenhoven (2009). This could support Hull's (1998) proposal that the languages of the Kei and Tanimbar Archipelagoes in Southeast Maluku are the easternmost representatives of "Proto Santalic".

All three Southeast Malukan languages have lost derivational affixation, as is displayed in Table 7 in the previous section. From a synchronic point of view, the Tanimbar languages seem most complex morphologically. Fordata now has eleven affixes, whereas Yamdena has six. Notwithstanding the incomplete information on Yamdena, we hypothesize that Fordata displays the most conservative structure of the Southeast Malukan languages. It is the only one with a cognate of PAN *-in-. Seven of its prefixes also occur in Ewaw and Yamdena, while the latter also has a prefix which is attested in Fordata but not in Ewaw. From a diachronic point of view, Ewaw was once morphologically more complex than its co-geners in that it seemed to have almost doubled its number of prefixes, which then fell into disuse.

The Ewaw case poses the linguist a problem: Why does a language first develop a morphology whose exorbitance exceeds any other language in the region and then stops using it almost completely without "shedding it off"? With the exception of the subject agreement markers, nowadays Ewaw speakers no longer distinguish separate prefixes on verbs. The sound changes in the Island Dialect have blurred the relationship between the "anorganic final consonants" and metathesis, because of which allomorphic variation seems arbitrary and unmotivated to its speakers and is often even non-existent. ${ }^{33}$

McWhorter (2008) explains grammatical simplification as a consequence of adult non-native acquisition. This is conceivable in a scenario in which Ewaw was being used as a trade language in the region. Roy Ellen (2003: 65 and further) describes a trade network in Maluku which connected the Banda Islands to the Onin Peninsula in New Guinea from the sixteenth to the eighteenth century, in which the Kei people maintained the link between the Aru Islands and Southeast Seram. However, it is not known whether Ewaw was used as a lingua franca or contact language then.

Van Engelenhoven (2003) says that, before their relocation to Seram Island in 1970s, the islanders of Teun, Nila, and Serua in Southwest Maluku maintained a trade network between the Banda Islands, Southwest and Southeast Maluku. The late Mr Workala (personal communication 2000) gave the information that Serua traders used Ewaw in trade in the Kei Archipelago until very recently. In a personal communication in 1997, Mr Letsoin El Ew

\footnotetext{
32 See, however, René van den Berg's (2003: 111, footnote 6) and Schapper's (2020) reactions.

${ }^{33}$ It was exactly this observation, because of which the Yar-Nain association in Zwolle searched for a unified spelling, which would make allomorphic changes predictable and, as such, would make learning Ewaw easier.
} 
affirmed that in the 1930s and 1940s Kei people trading in the Aru Archipelago would use Ewaw as a contact language, but that they would use Fordata in the north of Tanimbar. ${ }^{34}$

J.P. Rahail (2000) elaborates that the Ewaw-speaking communities in the Tayando and Kei Archipelagoes divide into twenty-two kingdoms or rat skap, ${ }^{35}$ which group into three traditional alliances: Ur siu (buffalo nine) 'Nine Buffalos', Lour Lim (sperm whale five) 'Five Sperm Whales', and the neutral Lour Labai (sperm whale labai) 'Labai Central Sperm Whale'. These three alliances all acknowledge the traditional law system of the "Red Blood and Balinese Spear", Lar Wuil - Nga Bal, which is generally considered to have been introduced from Bali. Local folklore mentions five regions from which the archipelagoes have been populated: Bal-Sumbau 'Bali-Sumba' ${ }^{\prime 36}$, Lun-Let 'Luang-Leti' - alternatively also Lun-Mobes 'Luang-Maubesi (in Timor)' -, Seran-Ngoran 'Seram-Gorom', Dolo-Ternat 'Jailolo-Ternate', and Bugis-Makassar. ${ }^{37}$ Of these, Rahail (2000) states that Dolo-Ternat is a derogatory term referring to the time before the introduction of the Lar Wuil - Nga Bal system. Dedi Supriadi Adhuri (2006) suggests that Islam was introduced with the arrival of the last-mentioned around the turn of the nineteenth into the twentieth century. However, Muslim clerics from Gorom Island appeared to have commenced proselytization among the Kei islanders long before the arrival of the Dutch in the seventeenth century (J.G.F. Riedel 1886: 162). In other words, there seems to have been a long record of contact between the archipelagoes and the outside world. Consequently, it is difficult to pinpoint whether or not it had an effect on the complexity of the morphological make-up in Ewaw.

When Geurtjens (1921a) published his grammar, Ewaw derivational morphology had already become obsolete. The periphrastic constructions discussed in Section 3 might in some instances account as a "trade-off" (after Kaius Sinnemäki 2008) of derivational morphology. They are, however, found throughout East Nusantara. Although the complexity of the adverbial markers and its interpretation as a kind of verb serialization is not matched in any other language in the region, the phenomenon is also attested elsewhere in East Nusantara. The use of monovalent position verbs in transitive constructions seems confined to all descendants of Proto-Southeast Maluku.

As far as we can see now, there is no indication that any of the surrounding indigenous languages had an impact on Ewaw. If Ewaw's simplification is related to the development of the trade networks in Southeast and Central Maluku, then it would be legitimate to suggest that local Malay (whether this be Ambon Malay or another variant) was the agent of simplification, because Malay had already been established as a trade language in Central Maluku

\footnotetext{
${ }^{34}$ Since Ewaw and Fordata are closely related, it is possible that Mr Workala's informants did not distinguish them as separate languages and called both Ewaw (or probably "Keiese"). The Ethnologue mentions Fordata as the former trade language of the Tanimbar Islands.

${ }^{35}$ Compounded from rat 'king' in the Island Dialect and skap, which derives from the Dutch nominal suffix -schap.

${ }^{36}$ Sumbau is actually expected to have been derived from Sumbawa rather than Sumba.

${ }^{37}$ Djonnie Rahantoeknam (2003) locates these migrations from 1500 onward.
} 
for centuries (Scott H. Paauw 2008:11). ${ }^{38}$ Just as the Island Dialect has lost the allomorphic distinctions through metathesis and these are now discernable only in the North variant of the Mainland Dialect, it is not beyond the scope of the imagination that the consonant clusters related to the consonant prefixes eventually might also reduce, after which the 'shedding off' of obsolete morphemes will finally take place.

\section{AbBreViations}

$\begin{array}{ll}- & \text { Morpheme boundary } \\ \sim & \text { Boundary with external metathesis } \\ \text { 1SG } & \text { Clitic boundary } \\ \text { 1SGP } & \text { First person singular pronoun/pronominal affix } \\ 2 \text { SG } & \text { First singular person possessive pronoun/pronominal affix } \\ 2 \text { SGP } & \text { Second person singular pronoun/pronominal affix } \\ \text { 3SG } & \text { Second person singular possessive pronoun/pronominal affix } \\ \text { 3SGP } & \text { Third person singular pronoun/pronominal affix } \\ \text { 1PLINC } & \text { Third person possessive pronoun/pronominal affix } \\ \text { 1PLEX } & \text { First person plural inclusive pronoun/pronominal affix } \\ 2 \mathrm{PL} & \text { First person plural exclusive pronoun/pronominal affix } \\ \text { 3PL } & \text { Second person plural pronoun/pronominal affix } \\ \text { ADJ } & \text { Third person singular pronoun/pronominal affix } \\ \text { ADV } & \text { Adjective } \\ \text { CAUS } & \text { Adverb } \\ \text { COND } & \text { Causative affix } \\ \text { EXC } & \text { Condition affix } \\ \text { N } & \text { Exclamatory prefix } \\ \text { NEG } & \text { Noun } \\ \text { NUM } & \text { Negative marker } \\ \text { PROC } & \text { Numeral } \\ \text { SEQ } & \text { Process affix } \\ \text { SP } & \text { Sequential marker } \\ \text { V } & \text { Speaker } \\ & \text { Verb }\end{array}$

\section{REFERENCES}

Adhuri, Dedi Supriadi. 2006. "Concept of origin and origin structure of the Austronesians; A reflection from Kei Islands in Southeastern Maluku”, in: Truman Simanjuntak, Ingrid H.E. Pojoh, and Mohammad Hisyam (eds), Austronesian diaspora and the ethnogeneses of people in Indonesian Archipelago, pp. 392-411, Jakarta: Lembaga Ilmu Pengetahuan Indonesia.

Berg, René van den. 2003. "The place of Tukang Besi and the Muna-Buton languages", in: John Lynch (ed.), Issues in Austronesian historical phonology,

\footnotetext{
${ }^{38}$ In a personal communication, Jim Collins points out that the use of war-and the double marking of causatives reminds him of the use of ber- and the confixes per- $-k a n$ and per- $-i$ in Indonesian/Malay, for example, Ewaw waha- $n$ (juice-N) 'juice': war-waha- $n$ 'juicy' $\sim$ Indonesian air 'water/juice': ber-air 'juicy' and douk 'sit': fa-doku-ng (CAUs-sit-ng) 'repair (literally, make sit up)' $\sim$ Indonesian baik 'good': per-baik-i (CAUS-good-LOC) 'repair'.
} 
pp. 87-114. Canberra: Research School of Pacific and Asian Studies, Australian National University. [Pacific Linguistics 550.]

Blust, Robert. 1993. "Central and Central-Eastern Malayo-Polynesian", Oceanic Linguistics 32: 241-293.

Blust, Robert. 2003. "Three notes on early Austronesian Morphology", Oceanic Linguistics 42(2): 438-478.

Chlenov, Mikhael. 1976. Nasalenie Molukkskikh Ostrovov [The population of the Moluccan Islands]. Moscow: Nauka.

Chlenova, Svetlana F. 2010. “Zametki o jazyke Geser-Gorom s prilozheniem slovnika i obraztsov predlozhenij" [Notes on the Geser-Gorom language with a wordlist and a sample of sentences], in: Artem Fedorchuk (ed.), Studia Anthropologica; Sbornik statej b chest' M.A. Chlenova, pp. 360-386. Moskva: Mosty Kultury, Jerusalem: Gesharim.

Collins, James T. 1982. "Linguistic research in Maluku; A report of recent fieldwork", Oceanic Linguistics 21: 73-146.

Collins, James T. and Timo Kaartinen. 1998. "Preliminary notes on Bandanese, language maintenance, and change in Kei", Bijdragen tot de Taal-, Land-, en Volkenkunde 154(4): 521-570.

Coward, David Forrest. 1990. "An introduction to the grammar of Selaru". MA thesis, the University of Texas, Arlington.

Donohue, Mark. 2004. "Typology and linguistic areas", Oceanic Linguistics 43(1): 221-239.

Donohue, Mark and Charles E. Grimes. 2008. "Yet more on the position of the languages of eastern Indonesia and East Timor', Oceanic Linguistics 47(1): 114-158.

Drabbe, P. 1926a. Spraakkunst der Fordaatsche taal. 's Gravenhage: Martinus Nijhoff, Weltevreden: Albrecht. [Verhandelingen Bataviaasch Genootschap 67.]

Drabbe, P. 1926b. Spraakkunst der Jamdeensche taal. 's Gravenhage: Martinus Nijhoff, Weltevreden: Albrecht. [Verhandelingen Bataviaasch Genootschap 67.]

Drabbe, P. 1932, Woordenboek der Fordaatsche taal.'s Gravenhage: Martinus Nijhoff, Weltevreden: Albrecht. [Verhandelingen Bataviaasch Genootschap 71.]

Dyen, Isidore. 1965. A lexicostatistical classification of the Austronesian languages.

Baltimore, MD: Waverly Press. [International Journal of American Linguistics Vol. 31 No. 1; Memoir 19.]

Ellen, Roy. 2003. On the edge of the Banda zone; Past and present in the social organization of a Moluccan Trading Network. Honolulu, HI: University of Hawaii Press.

Engelenhoven, Aone van. 1993. "[Review of] Donald A. Burquest and Wyn D. Laidig (eds), 1993, Phonological studies in four languages of Maluku", Cakalele Maluku Research Journal 4. [Retrievable at: http://scholarspace. manoa.hawaii.edu/bitstream/ 10125/4133/1 / UHM.CSEAS. Cakalele. v4.VanEngelenhoven.pdf.] 
Engelenhoven, Aone van. 2002. “Concealment, maintenance, and renaissance; Language and ethnicity in the Moluccan community in The Netherlands", in: David Bradley and Maya Bradley (eds), Language maintenance for endangered languages; An active approach, pp. 272-309, London: Curzon Press. Engelenhoven, Aone van. 2003. "Language endangerment in Indonesia; The incipient obsolescence and acute death of Teun, Nila, and Serua (Central and Southwest Maluku)", in: Mark Janse and Sijmen Tol (eds), Language death and language maintenance; Theoretical, historical and descriptive approaches, pp. 49-80. Amsterdam: John Benjamins. [Current Issues in Linguistic Theory 240.]

Engelenhoven, Aone van. 2004. Leti, a language of Southwest Maluku. Leiden: KITLV Press. [VKI 221.]

Engelenhoven, Aone van. 2009. "The position of Makuva among the Austronesian languages of East Timor and Southwest Maluku", in: K. Alexander Adelaar and Andrew Pawley (eds), Austronesian historical linguistics and culture history; A festschrift for Bob Blust, pp. 425-441, Canberra: Australian National University. [Pacific Linguistics 601.]

Engelenhoven, Aone van. 2010. "Deixis", in: Patrick Colm Hogan (ed.), Cambridge Encyclopedia of the Language Sciences, pp. 347-248, Cambridge: Cambridge University Press.

Geurtjens, H. 1921a. Spraakleer der Keieesche taal. 's Gravenhage: Martinus Nijhoff, Weltevreden: Albrecht \& Co. [Verhandelingen Bataviaasch Genootschap 63.]

Geurtjens, H. 1921b. Woordenlijst der Keieesche taal. 's Gravenhage: Emmink. [Verhandelingen Bataviaasch Genootschap 63.]

Geurtjens, H. 1924. Keieesche legenden. 's Gravenhage: Martinus Nijhoff, Weltevreden: Albrecht. [Verhandelingen Bataviaasch Genootschap 65.]

Gil, David and Antoinette Schapper (eds). 2020. Austronesian undressed; How and why languages become isolating. Amsterdam: John Benjamins.

Hageman, Dany. 2004. “Derivationele morfologie van het Ewaw”. MA thesis, Leiden University.

Hughes, Jock. 1987. “The languages of Kei, Tanimbar, and Aru; A lexicostatistical classification", NUSA 27: 71-111.

Hughes, Jock. 2000. "The morphology of Dobel, Aru, with special reference to reduplication", in: Charled E. Grimes (ed.), Spices from the East; Papers in languages in eastern Indonesia, pp. 131-180. Canberra: Research Scool of Pacific and Asian Studies, Australian National University. [Pacific Linguistics 503.]

Hull, Geoffrey. 1998. “The basic lexical affinities of Timor's Austronesian languages; A preliminary investigation", Studies in Cultures and Languages of East Timor 1: 97-202.

Hull, Geoffrey. 2004. "The languages of East Timor, some basic facts" (revised 28.4.2004). [Retrieved from: http://web.archive.org/ web/20060917145039/www.asianlang. mq.edu.au/ INL/langs.html; accessed on 4-10-2020.] 
Hull, Geoffrey and Sabil José Branco. 2002/3. “O Enígma da Língua Lóvaia”, Studies in Languages and Cultures of East Timor 5: 107-134.

Jonker, J.C.G. 1906. "Over de eind-medeklinkers in het Rottineesch en het Timoreesch", Bijdragen Koninklijk Instituut voor Taal-, Land-en Volkenkunde I 59: 263-343.

Kakerissa, O., Ny.J. Kasihuw, and J. Tamaela. 1996. Struktur bahasa Banda. Jakarta: Pusat Pembinaan dan Pengembangan Bahasa, Departemen Pendidikan dan Kebudayaan.

Klamer, Marian, Ger Reesink, and Miriam van Staden. 2008. “East Nusantara as a linguistic area", in: Pieter Muysken (ed.), From linguistic areas to areal linguistics, pp. 95-150. Amsterdam: John Benjamins. [Studies in Language Companion Series 90.]

Lewis, Paul, Gary F. Simons, and Charles D. Fennig (eds). 2015. Ethnologue; Languages of the World. Dallas, TX: SIL International. [Web version retrievable at: http:/ / www.ethnologue.com.]

Marshall, Craig. 2000. "A phonological description of Fordata", in: Charles E. Grimes (ed.), Spices from the East; Papers in languages in eastern Indonesia, pp. 181-235. Canberra: Research Scool of Pacific and Asian Studies, Australian National University. [Pacific Linguistics 503.]

Mills, Roger F. 1991. "Tanimbar-Kei; An eastern Indonesian subgroup”, in: Robert Blust (ed.), Currents in Pacific Linguistics; Papers on Austronesian languages and ethnolinguistics in honour of George W. Grace, pp. 241-263. Canberra: Department of Linguistics, Australian National University.

McWhorter, John. 2008. "Why does a language undress? Strange cases in Indonesia”, , in: Matti Miestamo, Kaius Sinnemäki, and Fred Karlsson (eds), Language complexity, typology, contact, change, pp. 167-190. Amsterdam: John Benjamins. [Studies in Language Companion Series 94.]

McWhorter, John. 2011. Linguistic simplicity and complexity; Why do languages undress? Berlin: De Gruyter Mouton. [Language Contact and Bilingualism 1.]

Mettler, Toni and Heidi Mettler. 1990. "Yamdena phonology", Working Papers in Indonesian Language and Culture 8: 29-79.

Paauw, Scott H. 2008. The Malay contact varieties of Eastern Indonesia; A typological comparison. PhD thesis, State University of New York, Buffalo.

Rahail, J.P. 2000. Adat en het beheer van land en zee op Kei. Utrecht: Moluks Historisch Museum, Landelijk Steunpunt Educatie Molukkers.

Rahantoeknam, Djonnie. 2003. "De Keiese geschiedenis". [Manuscript.]

Riedel, J.G.F. 1886. De sluik- en kroesharige rassen tusschen Selebes en Papua. 's Gravenhage: Martinus Nijhoff.

Rijkhof, J. 1991. "Nominal aspect", Journal of Semantics 8: 291-309.

Schapper, Antoinette. 2020. “The origins of isolating word structure in eastern Timor", in: David Gil and Antoinette Schapper (eds), Austronesian Undressed; How and why languages become isolating, pp. 391-446, Amsterdam: John Benjamins. 
Sinnemäki, Kaius. 2008. "Complexity trade-offs in a cross-linguistic perspective", in: Matti Miestamo, Kaius Sinnemäki, and Fred Karlsson (eds), Language complexity, typology, contact, change, pp. 67-88. Amsterdam: John Benjamins. [Studies in Language Companion Series 94.]

Steinhauer, Hein. 2009. "The sounds of Southeast Babar", in: K. Alexander Adelaar and Andrew Pawley (eds), Austronesian historical linguistics and culture history; A festschrift for Bob Blust, pp. 91-106. Canberra: Australian National University. [Pacific Linguistics 601.]

Tetelepta, J. et al. 1985. Struktur bahasa Kei. Jakarta: Pusat Pembinaan dan Pengembangan Bahasa, Departemen Pendidikan dan Kebudayaan.

Travis, Ed. 1993. "Bahasa Kei (Evav); Hasil penelitian selama satu abad", Penyelidikan bahasa dan perkembangan wawasannya 1, pp. 668-686. Ambon: Universitas Pattimura, SIL.

Travis, Ed. 1997. “Kei dictionary”. [Manuscript.] 